$\frac{\text { DE }}{\bar{C}} \begin{array}{ll}\text { DE GRUYTER } & \begin{array}{l}\text { Asian Journal of } \\ \text { Comparative Law }\end{array}\end{array}$

The Difference that Religion Makes: Transplanting Legal Ideas from the West to Japan and India

\begin{tabular}{|r|l|}
\hline Journal: & Asian Journal of Comparative Law \\
\hline Manuscript ID: & Draft \\
\hline Manuscript Type: & Article \\
\hline Classifications: & N/A \\
\hline Keywords: & Legal transplants, Religion, Japan, India, Christianity \\
\hline
\end{tabular}

SCHOLARONE ${ }^{m}$

Manuscripts 


\title{
The Difference that Religion Makes: \\ Transplanting Legal Ideas from the West to Japan and India
}

\begin{abstract}
What is the fate of legal transplants when they arrive from one culture, the Western culture, which is religious, to another culture that has no religion? Using the theoretical framework of legal transplantation developed by Masaji Chiba and the theory of religion developed by S.N. Balagangadhara the problem is tested with two different types of indigenous law, drawn from cultures - Japan and India. Dysfunctional effects result when certain kinds of legal ideas, embedded as norms within the Western culture, which is constituted by a religion, Christianity, are transplanted into those non-Western cultures that do not have religion. Religion and the ideas linked to it (such as the freedom of religion and the separation of religion and state) break down, and become distorted, absurd or nonsensical, and potentially conflict-inducing when placed in a culture without religion. This occurs as the secular state engages in the process of suppressing what it implicitly regards as false religion or idolatrous practices existing within the indigenous culture of a people. As Chiba foresaw, this process can even lead to the identity postulate of a legal culture being altered or destroyed.
\end{abstract}

\section{Introduction}


Masaji Chiba's contributions to the study of law are vital. ${ }^{1}$ He was a strong Asian voice amidst the hubristic cacophony created by Western legal theorists, which has been crowding out other voices in the world. His insights are largely overlooked by Western legal scholars and this continues to be the case even within studies connected to the field of legal pluralism to which he contributed the most among Asian scholars. ${ }^{2}$ This may be because he often saw through the problems and deficiencies inherent to "Western model jurisprudence" which was parasitically adopted by non-Western scholars and countries, and he was not afraid to say so openly, or as he would say, "frankly"! This overlooking is to the detriment of legal scholarship generally. My own experience is that one can go back repeatedly to Chiba's works to discover previously unnoticed insights.

Werner Menski first introduced me to Chiba's work, and I began to take a deeper look at what Chiba was writing in connection with my work on cultural diversity and legal pluralism in the British context. ${ }^{4}$ At the time, I was not yet preoccupied by the question of religion to the extent I subsequently came to be. Eventually, perhaps, the $9 / 11$ effect took hold of me too! I received a

\footnotetext{
${ }^{1}$ This article emerges from a presentation originally made by the writer at the Chiba Memorial Symposium: Towards a General Theory of Legal Culture in a Global Context, at the School of Law, SOAS, University of London 26 March 2012.

${ }^{2}$ For example, see the absence of reference to Chiba's work in Martha-Marie Kleinhans \& Roderick A. Macdonald, "What is a Critical Legal Pluralism?" (1997) 12 Canadian Journal of Law \& Society 25; Franz von BendaBeckman, "Who's Afraid of Legal Pluralism?" (2002) 47 Journal of Legal Pluralism and Unofficial Law 37; and Brian Z. Tamanaha (2007): "Understanding Legal Pluralism: Past to Present, Local to Global" (2007) 29 Sydney Law Review 375; and the dismissive way in which Chiba's work is treated by Emmanuel Melissaris, Ubiquitous Law: Legal Theory and the Space for Legal Pluralism (Aldershot: Ashgate, 2009).

${ }^{3}$ Chiba's critique of 'legal culture', in prevalent use among Western scholars, and infected by their preoccupation with state law, is one example. See Masaji Chiba, "Japan" in Poh-Ling Tan, ed, Asian Legal Systems: Law, Society and Pluralism in East Asia (Sydney et al: Butterworths, 1997) at 83-86; Masaji Chiba, "Other Phases of Legal Pluralism in the Contemporary World" (1998) 11 Ratio Juris 228.

${ }^{4}$ ??.
} 
Chiba Grant ('Beca Chiba') to study at the International Institute for the Sociology of Law at Oñati, Spain in 2005, specifically on the question of religious reconstruction among Britain's South Asian diasporas. ${ }^{5}$ Probably, Chiba had presciently realized that studies of non-Western law would be neglected in Western legal circles and made sure that the grant he had endowed was dedicated to that potentially enormous field of research. ${ }^{6}$ Meanwhile, the bombings in London of 7/7 took place just a few days before my wife and I arrived in Oñati. This was the start of a concern with religion and law which is still with me and which I now attempt to take beyond the British context.

In his English language writing, Chiba does not elaborate about his idea of religion and he certainly does not try to lay out some kind of theory of religion. Rather, he is interested throughout his work to elaborate on and refine meta-level concepts in order to delineate the chief characteristics of legal pluralism, especially legal rules, legal and identity postulates, official and unofficial law, indigenous and transplanted law, trans-state law, and so on. How, then, does Chiba use the term 'religion'? Religion features as one aspect of legal pluralism in the theory set out by Chiba and, for him, it belongs under the general rubric of 'legal postulates'. ${ }^{7}$ Legal postulates inform official and unofficial laws by founding, justifying or orienting them and legal postulates are not exhausted by religion. Chiba's choice of the term 'legal postulates' seems to have been motivated partly by the fact that he figured out that the term 'natural law' was too

\footnotetext{
${ }^{5}$ For the outcomes of that research, see ??.

${ }^{6}$ Evidently, the Masters programme at Oñati has not been able to maintain a broad enough syllabus to ensure a sustained focus on non-Western laws.

${ }^{7}$ Masaji Chiba, ed, Asian Indigenous Law in Interaction with Received Law (London \& New York: KPI, 1986) at 67.
} 
identified with Western culture to be of use as a meta-level idea in a multicultural world. ${ }^{8}$ This was an interesting move by Chiba, in itself worthy of notice, in that it represents an instance of his attempts to specify the limit of concepts derived from one particular culture and to go beyond the Western concepts which were (and are) tying down legal theory within its Eurocentric cocoon. ${ }^{9}$

As a feature of Japanese culture Chiba regarded Shinto as a religion, describing it as "originally an indigenous folk religion", which was subsequently "ideologized as the State Shinto". ${ }^{10} \mathrm{He}$ saw Hindu law as a "religious law". "These observations are hardly exceptional to Chiba since the conventional wisdom in today's world is that Shinto is a type of religion, and so is Hinduism. It is still strange in most circles for people to say that neither Hinduism nor Shinto are religions; or that neither is even a coherent unit of discourse as generally implied by their portrayal as kinds of religious entities. Yet, these are precisely the sorts of claims that are made in this article, which will open up the possibility of asking further questions about Asian legal systems.

It is well known in some circles that a lively debate has been raging about the possibility or impossibility of legal transplants and the bearing that culture or the nature of societies has on the success or quality of legal transplantation. The protagonists in this debate have been Alan Watson and Pierre Legrand. ${ }^{12}$ Not untypically, Chiba's investigations into the problem were

\footnotetext{
${ }^{8}$ Masaji Chiba, Legal Pluralism: Toward a General Theory through Japanese Legal Culture (Tokyo: Tokai University Press, 1989) at 134-8.

${ }^{9}$ Chiba, ibid, similarly distanced himself from other concepts such as 'customary law' and 'positive law' because he found them too linked to the Western culture. For a deeper discussion of the specificity of Western jurisprudence, which Western scholars have hardly taken note of, see ibid at 27-56.

${ }^{10}$ Ibid at 92.

${ }^{11}$ Chiba, Asian Indigenous Law, supra note 7 at 385.

${ }^{12}$ Alan Watson, Legal Transplants: An Approach to Comparative Law, 2nd ed (Athens \& London: The University of Georgia Press, 1993); Alan Watson, "Legal Transplants and European Private Law" (2000) 4 Electronic Journal
} 
ignored by them. Chiba advised us to look deeper at the dynamics of transplanted law, which he defined as that law "which was received from foreign cultures or imposed by foreign countries". ${ }^{13}$ He advised that we should look at the whole working structure of a socio-legal entity from a historical viewpoint and should pay attention to its identity postulate in order to assess the fate of any transplantation. As Chiba noted:

the whole process and outcome must be viewed with the total history of the people concerned - a history in which they have endeavoured to preserve their cultural identity in law against other peoples. Here, then, is hypothesized one or more basic legal postulates of a country functioning throughout its history to provide the people with the criteria with which they are enabled to determine, from among many possibilities, what kinds of law they should develop selectively and ... what foreign law and to what extent it should be received or rejected in order to preserve their cultural identity in terms of law. Such a postulate or postulates cannot be of a received nature insofar as each group of people concerned has preserved its national identity in history, but must be of an indigenous nature, however it or they may have involved or assimilated received law. The "identity postulate of indigenous law" may thus be an appropriate name for such a postulate or postulates. ${ }^{14}$

Chiba saw that there were different identity postulates in different countries; Dharma in India, Shinto in Japan, and Islam in Iran or Egypt which do the work of selecting what transplanted laws are chosen and the way in which they function. Therefore, the reception of transplanted law

of Comparative Law http://www.ejcl.org/ejcl/44/44-2.html; Pierre Legrand, "The Impossibility of Legal Transplants” (1997) 4 Maastricht Journal of European \& Comparative Law 111.

${ }^{13}$ Chiba, "Other Phases", supra note 3 at 241.

${ }^{14}$ Chiba, Asian Indigenous Law, supra note 7 at 390. 
should tell us something about the nature of the identity postulate of any socio-legal entity and may also allow us to propose further hypotheses about the fate of transplanted laws. Chiba revised the description of the 'identity postulate' to account for legal change over time and for different foreign influences and he therefore renamed it the "identity postulate of a legal culture" so that the term may signify a combination of indigenous and transplanted factors. ${ }^{15} \mathrm{He}$ drew attention to the possibility of competition and struggle as well as a change in an identity postulate, as a result of negligible, transformative or destructive influences. This article points to just such a potential for change within socio-legal entities, albeit with as yet inconclusive results.

The question here is: what is the fate of legal transplants when those transplants arrive from one culture, the Western culture, which is religious, to another culture that has no religion? To test the fate of received law, I take two different types of indigenous law, drawn from cultures whose identity postulates are derived from non-Semitic or 'pagan' elements - Japan and India. In both cases we try to discover what occurs when religion and ideas linked to it are transplanted from the Western culture. The more specific claim here is that dysfunctional effects result when certain kinds of legal ideas, embedded as norms within the Western culture, which is constituted by a religion, Christianity, are transplanted into those non-Western cultures that do not have religion. I want to specifically discuss the fate of ideas linked religion such as the freedom of religion and the separation of religion and state, as enacted within the legal orders of nonWestern countries. The further claim here is that these break down, get distorted, become absurd or nonsensical, and even potentially conflict-inducing when placed in a culture where the identity postulates are not religious. As Chiba foresaw, this process can even lead to the identity postulate of a legal culture being altered or destroyed. This occurs as the secular state engages in the

\footnotetext{
${ }^{15}$ Chiba, Legal Pluralism, supra note 8 at 166-9.
} 
process of suppressing what it implicitly regards as false religion or idolatrous practices existing within the indigenous culture of the people.

\section{Religion}

A number of researchers have argued that that the type of religion presupposed by studies of comparative religion and the social sciences more generally is Christianity, or they have voiced doubts about the validity of the claim that religion is a property of all cultures. ${ }^{16}$ The strongest challenge against the claim of universality of religion has been mounted by S.N. Balagangadhara and his seminal research programme on the Comparative Science of Cultures. ${ }^{17}$ Balagangadhara's work has attracted some critical acclaim among scholars although it must be said, at the same time, that those Western scholars with whom I have had discussions are not willing to engage properly with his work, which is to the general detriment of various fields in the human sciences, including law. ${ }^{18}$ Even though law and religion studies have attracted much research funding in recent years we find no serious attention to Balagangadhara's work in that connection. $^{19}$

\footnotetext{
${ }^{16}$ See, for example, the discussion and authors cited by Markus Dressler \& Arvind Mandair, eds, Secularism and Religion-Making (Oxford: Oxford University Press, 2011) at 16-18.

${ }^{17}$ See, especially, S. N. Balagangadhara, "The Heathen in his Blindness...": Asia, the West, and the Dynamic of Religion (Leiden, New York: E. J. Brill, 1994; 2nd rev. ed, New Delhi, Manohar, 2005; reference here is to the 1st ed). For an abridged version, see S. N. Balagangadhara, Do All Roads Lead to Jerusalem? The Making of Indian Religions (New Delhi: Manohar, 2014).

${ }^{18}$ See the set of review essays on Balagangadhara, The Heathen, ibid, in the special issue (1996) 8(2) Cultural Dynamics. In experience and research so far, most writers who otherwise comment on the book tend to undermine its claims by misrepresenting them.

${ }^{19}$ Ten Chin Liew, "Secularism and its Limits" in Michael S. H. Heng \& Ten Chin Liew (eds), State and Secularism: Perspectives from Asia (Singapore: World Scientific Publishing, 2010) 7 raises expectations by referring to one
} 
Balagangadhara draws attention to an often encountered inconsistency involved when the criteria indispensible to describing the Semitic religions - God, holy books, founders, doctrines etc. - are the very ones dispensed with when applied to other traditions while claiming they are religions too. He shows by reference to Christian sources (but which is shared by Islam and Judaism) that the claim of religion being a universal despite this inconsistency can be put down to theology. Balagangadhara shows that this pre-theoretical and empirically untested theological assumption has subsequently seeped into the social sciences in secularized form. That is why the social sciences today also claim that all cultures have religion. Taking the point further, with reference to historical evidence, he shows also how Europeans when travelling to Asia and other lands 'discovered' religion because it was a presupposed property of other cultures, and how they brought unrelated phenomena together under the rubric of various 'religions'. We will return to this point.

Balagangadhara also offers a hypothesis of religion. He does not assert the existence of religion as a matter of mere language or discourse as other writers who build, for instance, on Wittgenstein or Foucault have done. ${ }^{20}$ Neither is Balagangadhara after a definition of religion. Rather, he wants to examine religion as a phenomenon in the world and draws out its properties by proposing a hypothesis of religion. ${ }^{21}$ Balagangadhara does not, however, argue that language

article by Balagangadhara and De Roover but is unable to pursue its consequences and writes in ignorance of the research programme.

${ }^{20}$ A notable figure here is Talal Asad, Genealogies of Religion: Discipline and Reasons of Power in Christianity and Islam (Baltimore, Maryland: The Johns Hopkins University Press, 1993).

${ }^{21}$ Thus Balagangadhara's task is quite different to, for example, Prasenjit Duara, "An East Asian Perspective on Religion and Secularism" in Michael S. H. Heng \& Ten Chin Liew (eds), State and Secularism: Perspectives from Asia (Singapore: World Ten Chin Liew Scientific Publishing, 2010) 1 at 2 where he says: "It is obviously meaningless to talk about whether or not religion existed in history; it has everything to do with how one defines the 
use must not be taken seriously. It should, but it can provide us with a picture only of some conventional understanding, which may not be universal, but particular to a culture. He narrows down the search by examining the terms under which Judaism, Christianity and Islam recognize themselves and others as religions. ${ }^{22}$ These terms are as follows: (a) rivalry with respect to doctrinal aspects including in relation to the nature and existence of God; (b) that beliefs determine the difference between individuals and between communities; (c) because the actions of the faithful are embodiments of such beliefs, the different practices of individuals - to the extent these are relevant to religious practices - are expressions of competing religious beliefs; (d) consequently, that conversion from one religion to another means a rejection of one set of beliefs and practices and embracing another set on grounds of truth and falsity, it being vital and necessary that believers believe in the truth of their beliefs. Using this 'Semitic concept of religion', Balagangadhara is able to explain, in a single hypothesis, why, on the one hand, Judaism, Christianity and Islam recognized themselves, each other, and certain others as religions under particular terms of description and, on the other hand, why the pagan traditions of Rome and India did not recognize themselves and the others (Judaism, Christianity and Islam) under these terms of description. That is why the followers of these traditions could only respond with indifference and incomprehension to the characterization of religious rivalry.

While Judaism, Christianity and Islam may be exemplary instances of religion, Balagangadhara proposes that religion itself, which all three share, is an "explanatory intelligible account of both the Cosmos and of itself'. ${ }^{23}$ This account says that the cause of the Cosmos eiais the Will of

term." Definitional exercises will have limited consequences in terms of generating knowledge about a phenomenon where theory building is required.

${ }^{22}$ Balagangadhara, The Heathen, supra note 17 at 295-6.

${ }^{23}$ Ibid at 298-318. 
God, and all that was, is and will be is an expression of His Will. God's intentions can be known by studying the Cosmos and His revelation. This kind of account fuses God's intentions or reasons for acting and the causes of His actions into a single explanation; He is the perfect being whose reasons can be read off his actions, which are His creation and the revelation He sent. A religious person thus experiences the Cosmos as both a causally explainable and an intelligible entity, a way of structuring the experience of the world that is not available to those without religion. Life is part of a bigger plan, and human life and death have a meaning and purpose, making it possible to ask questions about that meaning and purpose, answers to which are to be discovered. Within a religion, faith distinguishes a truly religious person from one who merely accepts that God is a creator of the Cosmos and follows its ethical rules. Faith allows the making of a distinction between those who adhere and do not adhere to religious truth (there can only be one truth), and to have faith is the other side of the coin to being intolerant, since a believer cannot accept that other religions are 'equally true'. As Balagangadhara notes, "Intolerance, then, is necessary to being a religious person." 24

That people from cultures which have religion also have a cognitive compulsion to 'find' religion in other cultures was also sensed by Staal, who observed that:

The inapplicability of Western notions of religion to the traditions of Asia... is also responsible for something more extraordinary: the creation of so-called religions. This act was primarily engaged in by outsiders and foreigners, but is sometimes subsequently accepted by members of a tradition. The reasons lie in the nature of Western religion ... In most parts of Asia, such religions do not exist, but scholars, laymen and Western converts persist in searching for them. If they cannot find them, they seize upon labels used for

\footnotetext{
${ }^{24}$ Ibid at 312.
} 
indigenous categories, rent them from their original context and use them for subsequent identification of what is now called a "religious" tradition. Thus there arises a host of religions: Vedic, Brahmanical, Hindu, Buddhist, Bon-po, Tantric, Taoist, Confucian, Shinto, etc. In Asia such groupings are not only uninteresting and uninformative, but tinged with the unreal. ${ }^{25}$

First of all, Staal's claim about the inapplicability of Western notions of religion to Asian traditions (by "Western" Staal refers to all three Semitic religions) seem analogous to Jun'ichi Isomae's reference to Seki Kazutoshi and Ama Toshimaro who, says Isomae "agreed that the Western concept of religion was not suited to the analysis of non-Western religious phenomena". ${ }^{26}$ In effect, both say that we require a more extended concept of religion that fits Asian religious phenomena. ${ }^{27}$ At this point, the usefulness of Balagangadhara's theory becomes more evident. Balagangadhara's own evidence shows how the terms of description of the Semitic religions were incomprehensible to followers of the Roman pagan and Indian traditions. Rather than arguing for the stretching of the concept of religion to fit Asian realities, which he already identifies as having been routinely done to account for Asian phenomena, and which he shows as resulting in contradictory ideas of religion, he accounts for why the Semitic concept of religion makes no sense to those from Asian cultures. It makes no sense because they lack an explanatory intelligible account; ergo they lack religion. His theory therefore explains why the doctrinal rivalry inherent to the Semitic religions is incomprehensible to Asians and why they are indifferent to it. Rather than explaining that Japanese beliefs "in the workings of unseen

\footnotetext{
${ }^{25}$ Frits Staal, Rules without Meaning: Ritual, Mantras and the Human Sciences (New York: Peter Lang, 1989) at 393.

${ }^{26}$ Isomae Jun'ichi, Religious Discourse in Modern Japan: religion, State, and Shintō (Leiden: Brill, 2014) 19.

${ }^{27}$ Staal, supra note 25 actually holds other inconsistent positions that would inter alia restrict the term 'religion' to the Western monotheisms. See for a critique Balagangadhara, The Heathen, supra 17 note at 282-7.
} 
presences" are evidence of a form of religiosity, Isomae would have been better off adopting Balagangadhara's better explanation for Isomae's own observation that: “So, because Japanese are uncomfortable in using the word 'religion', with its connotations connected to Christianity, they often want to assert that they do not want to believe in 'a religion,' and end up expressing the difference by saying 'Japanese are not religious.",28

Staal also noticed that there was something 'unreal' about the groupings constructed by outsiders and foreigners. Balagangadhara explains the status of these 'creations' in the following way:

the West did two things: (a) created 'Hinduism' and 'Buddhism' etc. as coherent and structured units and (b) did so as religions. The issue is not whether western culture created a monolithic religion instead of recognizing the multiplicity of theories and practices that go under the label 'Hinduism'. It is not even whether they experienced 'Hinduism' as a monolithic entity. Instead, it lies in the fact that 'Hinduism', as a concept and as an experiential entity, provided the westerners with a coherent experience. To the extent it is a concept, it is a human construct, like all other concepts. It is also a construct because, as an experiential entity, it unifies the western experience. However, this concept has no reference in the world, i.e., there is no 'Hinduism' (whether as a religion, or as a multiplicity of religions) in the Indian culture. ${ }^{29}$

Balagangadhara explains further the ontological status of the "experiential entity" that is Hinduism:

\footnotetext{
${ }^{28}$ Isomae, Religious Discourse supra note 26 at xiv.

${ }^{29}$ S.N. Balagangadhara, "Orientalism, Postcolonialism and the 'Construction' of Religion” in E. Bloch, M. Keppens $\&$ R. Hegde, eds, Rethinking Religion in India: The Colonial Construction of Hinduism (London, Routledge, 2010) 135 at 138 .
} 
In his Orientalism, Said distinguishes between the Orient as a place and 'the Orient' as an entity that exists only in the western experience. Similarly, one could argue that 'Hinduism' is both a false description of Indian reality and it is an imaginary entity. It is false not because the West gave a false description of some reality ('Hinduism' in this case) but because they falsely assumed that their experiential entity was also a real entity in the world. It is imaginary in the sense that it does not have an existence outside the experience of western culture. ${ }^{30}$

Balagangadhara writes that, in the process of making an entity like Hinduism (or Shinto, for that matter), tradition is cast as another religion, and provided with a 'foundation' which inscribes its falsity. ${ }^{31}$ The otherness of the traditions, based as they are upon ancestral practices and human knowledge, thus disappears in this account: "Having no 'other', religion merely postulates other religions. It is impossible that India does not have religion; it merely has another religion."32 Perhaps we should speak about this process as 'anothering'. When religions were found, they were opposed to whichever idea of truth Europeans had brought with them and invariably described by them to be false religions. It followed that the practices of the natives identified as regressive, being inconsistent with the ethical values of the Europeans, should be reformed. This theme continues in secularized form today. In some cases, notably in the Americas and Africa, where Christianity has spread the most, there were even discussions about whether the native peoples were humans and therefore whether they could receive the Christian message.

After the Reformation, ideas specific to Protestantism, for example the split between the temporal and secular public sphere and the private realm of the conscience and religion, were

\footnotetext{
${ }^{30}$ Ibid.

${ }^{31}$ Balagangadhara, The Heathen, supra note 17 at 329-31.

${ }^{32}$ Balagangadhara, The Heathen, supra note 17 at 331.
} 
also brought to Asia. The Reformation had set one Christian movement against another, with Protestants claiming that Catholics (and other Protestants) were idolatrous, setting off a chain reaction that continues today. As De Roover explains, the chief problem the Protestants identified with Catholicism, and with other Protestants, was the presence of idolatry within their practices, while the realm of the 'secular' was conceptualized as containing the set of sanitized practices to which they were indifferent. ${ }^{33}$ The Enlightenment pushed this process further, with the state ideally becoming secular, thus not tied to any religion, while assuring freedom of religion and conscience. This phase of secularization was a consequence of, and implicitly carried forward, Protestant critiques in so far as they required a secular state as a way of guaranteeing that no man-made accretions should influence true worship. Otherwise it would amount to idolatry. ${ }^{34}$

The building blocks and "intelligibility conditions"35 of Enlightenment ethics, grounded as they are on a Christian anthropological framework, have since receded into the background within Western jurisdictions to the extent that the link of modern law to religion is often denied, the separation between law and religion is seen as incomplete, or such separation is criticized. As Balagangadhara points out:

the lines of distinction between the 'religious' and the 'secular' spheres are drawn within a religion. Historically speaking, this demarcation is the work of Christian theology and

\footnotetext{
${ }^{33}$ Jakob De Roover, "Secular Law and the Realm of False Religion" in Winnifred Fallers Sullivan, Robert A. Yelle \& Mateo Tausig-Rubbo, eds, After Secular Law (Stanford: Stanford University Press, 2011) 43.

${ }^{34}$ Such a claim was implicit in the famous Lautsi case (European Court of Human Rights, Case of Lautsi and Others v. Italy, Application no. 30814/06, judgment of 18 March 2011), where an atheist Italian parent demanded that the crucifixes displayed in all classrooms of the state school her children attended be removed.

${ }^{35}$ Jakob De Roover, Sarah Claerhout \& S.N. Balagangadhara, "Liberal Political Theory and the Cultural Migration of Ideas: The Case of Secularism in India" (2011) 39 Political Theory 571 at 583.
} 
our political theories are Christian theologies in disguise. The enlightenment thinkers repeated this Protestant story and this has become our 'secularism'. 36

This is part of the process which Balagangadhara identifies as 'secularization', which is one of two ways (the other being conversion) in which Christian theological ideas spread and become universalized. Secularization can therefore be seen as the extension of specific clusters of Christian ideas into the general or common place conceptual framework of a society, functioning as (topoi) which are either heuristic tools for the development of theories or components of such theories. ${ }^{37}$ As those topoi spread, they lose their ostensibly Christian character, and mix in various ways to assume their specific characteristics. Importantly, Christian commonplace ideas are also extended to other societies according to what is assumed to be a universal framework. While there may be a number of agencies for effecting secularization in this manner, legal transplants appear to be a key tool for generalizing Christian topoi in a secular guise. While modern Westerners have been losing their ability to relate contemporary secularized frameworks to their theological background, to Asians they have made even less sense, even though many Asians have taken over the Western description of the Asian cultures. Let us turn to the processes which were set in motion once religion was found or 'created' in Asian contexts.

\section{Japan}

Chiba draws our attention to the fact that, in its long history, Japan had extensive contacts and legal transplantation experiences, especially with Korea and China. ${ }^{38}$ However, the question of

\footnotetext{
${ }^{36}$ Balagangadhara, "Orientalism" supra note 29 at 143.

${ }^{37}$ De Roover et al, "Liberal Political Theory" supra note 35.

${ }^{38}$ Chiba, "Other Phases", supra note 3 at 89-94.
} 
religion did not arise until contact was made with the West. The introduction of Catholic Christianity to Japan in the $16^{\text {th }}$ century does not appear to have led to major legal reforms, although Catholicism was prohibited by the $17^{\text {th }}$ century. It did however give rise to the Japanese word for 'religion', shukyo, which is said to derive from the Chinese word, tsung-chiao, now often translated as 'the principles and teachings of Buddhism'. Otherwise, as Isomae observes, "In the Tokugawa period, however, Christianity was equated with Catholicism, which tended to be neglected by Japanese scholars in the modern era due to its ritualistic character." 39 Conversely, this indicates that they were not interested in doctrinal foundations for practices as the Christian themselves were. It underwrites Balagangadhara's observation that Asians cannot comprehend the nature of religion and view Christian practices as a tradition among other traditions.

During the Meiji period, and with increased contact with Western countries and the introduction of Protestantism in Japan, things began to change. The major controversies regarding religion started in the late $19^{\text {th }}$ century when there were several linked developments. Religious studies were established as a discipline at Tokyo University and later elsewhere. Several religions came to be identified including Buddhism, Shinto and Christianity. The process of anothering had been set in train. In a pattern that is reflected well in Japan (and in parallel Indian developments), Buddhism, for instance, began to be reconstructed with efforts being made to purge it of its “superstitious elements". ${ }^{40}$ The Greater Japan Imperial Constitution (Dai Nippon Teikoku Kenpo) was promulgated in 1889. Along with the sovereignty of the emperor, it formally established

\footnotetext{
${ }^{39}$ Isomae Jun'ichi, “Deconstructing 'Japanese Religion': A Historical Survey” (2005) 32 Japanese Journal of Religious Studies 235.

${ }^{40}$ Jason Ānanda Josephson, "When Buddhism became a 'Religion': Religion and Superstition in the Writings of Inoue Enryō" (2006) 33 Japanese Journal of Religious Studies 143. See further, Isomae, Religious Discourse supra note 26 at 98-118.
} 
Shinto as the state religion, while a stipulation for freedom of religion was also included. Already we see a transformation of the language here. Shinto was now regarded as the state religion while the vocabulary of religious freedom simultaneously became important. The dissemination of the Imperial Rescript on Education that same year likewise confirmed the government's intent to use Shinto to implement policies of national education, particularly a code of national morals.

Consistent with the splitting of the private and public spheres according to a Western logic, however, we find that this also led to a further tension within the Japanese political and legal system. As Isomae comments:

Broadly speaking, the debate over national morality refers to policies by the government and conservative elements to enlighten the people through moral instruction.... It was intended to coincide with the provision for religious freedom, with religious choice to be entrusted to each individual. But as policies of national education began to be seen as at odds with the constitutional guarantee of religious freedom, its proponents shifted the rhetoric of their argument to the need for moral instruction. During this time, Shinto gradually split into two camps: Religious Shinto, which followed denominational teachings, and Shrine Shinto, which, in addition to reverence for the portrait of the emperor, came to emphasize reverence for shrines as a moral obligation of the people in their loyalty to the Imperial system. As may be expected, there were naturally those who voiced misgivings that reverence for shrines and the portrait of the emperor constituted a 
form of religious conduct which conflicted with the beliefs of the individual and encroached upon religious freedom. ${ }^{41}$

The main lines of secularization were therefore becoming clear by the early years of the $20^{\text {th }}$ century. On the one hand, the split between religious Shinto and shrine Shinto was an attempt in Japan to correspond to the religion (private) - secular (state) divide. The problem remained, however, that the association of Shinto with formal state activity, for example through shrines and through education, was liable to be attacked on grounds of freedom of religion. ${ }^{42}$ On the other hand, there was also a feeling that Shinto was in need of protection against Christianity and Buddhism given that Shinto had been reduced to a 'folk religion' and this became an ingredient feeding the nationalist sentiment that Japanese culture was under assault. Events subsequently went out of control with the rise of militarism and the onset of the long Asian war. Since the Second World War, state Shinto has become associated with nationalism and sections of Japanese society take a position against state support of it. However, officials and organs of the state have since often supported Shinto ceremonies such as the commemoration of dead soldiers and seasonal rituals, demonstrating what Chiba had noted about the persistence of indigenous legal postulates in Japan. ${ }^{43}$

This more or less open support for Shinto co-exists with tensions created within the legal system against support for it. After the Second World War, the American occupation authorities issued an order for the dismantling of state Shinto. The Japanese Constitution enshrined in Article 20

\footnotetext{
${ }^{41}$ Isomae Jun'ichi, "The Discursive Position of Religious Studies in Japan: Masaharu Anesaki and the Origins of Religious Studies” (2002) 14 Method \& Theory in the Study of Religion 21 at 29.

${ }^{42}$ Ibid, especially at 28-30.

${ }^{43}$ See, for example, Masaji Chiba, "Japan" in Poh-Ling Tan, ed, Asian Legal Systems: Law, Society and Pluralism in East Asia (Sydney et al: Butterworths, 1997) 82.
} 
the freedom of religion, a prohibition upon the state conferring any privileges on any religious organization, a prohibition on compelling participation in religious acts, celebration, rite, or practice, and a prohibition on the state taking part in religious education or any other religious activity. It looks as though the model for this is the American 'wall of separation' between religion and the state. The vocabulary of freedom of religion, religious neutrality of the state, the secular nature of the state, and even the separation of Church and state are a constant feature of Japanese court judgements either upholding or rejecting challenges to state actions in support of 'religion'. These invariably involve ceremonies associated with Shinto, such as breaking the ground prior to the construction of a building, enshrinement of a member of the self-defence forces in a Gokuku (guardian of the state) shrine, and rituals at the Yasukuni shrines of the war dead. $^{44}$

What is remarkable for the purposes of the present article is not whether judges either support or reject claims against state involvement in Shinto ceremonies, but rather the confidence with which they use the kind of language referred to above, which is embedded within a Protestant framework, for understanding Japanese traditions. It raises questions about how such language makes sense to Japanese judges themselves, to officials, or to Japanese people who operate out of a cognitive framework of a completely different order; about how it relates to their experience of the world; and about how such a transplanted framework can be said to have been successfully absorbed into the Japanese legal order and society. Isomae draws attention to the fact that native elites as intellectuals and religious studies scholars have continued to act as the bearers of a conceptual discourse that was under the direct influence of Western society. Beyond grasping the

\footnotetext{
${ }^{44}$ Kenneth L. Port \& Gerald Paul McAlinn, Comparative law: Law and the Legal Process in Japan (Durham, N.C.: Carolina Academic Press, 2003) at 283-303.
} 
cultural gap between Japan and the Western world Isomae argues that, "One is also obliged to consider the dynamics of power internal to Japan that have involved the cultural hegemony of native elites, who are oriented towards the conceptual world of the West, over the general populace who remained outside the bounds of that world." 45 Thus, taking very seriously Chiba's claim that the fate of legal transplants is conditioned by the nature of the indigenous identity postulate of a socio-legal entity, we need to research more clearly how a framework developed within a culture that has religion is changed and distorted, and creates the potential for conflict, when it enters into an Asian cultural context where there is no religion.

\section{India}

European contact with India gave rise to several phases in the accumulation of knowledge and the construction of Indian realities in the experience of the West. ${ }^{46}$ Indians came to be regarded as ignorant, idolatrous, immoral, heathen devil worshippers held in their sorry state by wily priests, the Brahmins. ${ }^{47}$ Over time, several different 'religions' were constructed: Hinduism, Buddhism, Jainism and Sikhism and, by analogy with the Reformation critiques by Protestants of Catholicism, all of them, except Hinduism, were cast as protest or reform movements against the domination by Brahmins. As Oberoi has noted, new boundaries were being created. ${ }^{48}$ Thus the

\footnotetext{
${ }^{45}$ Isomae, Religious Discourse supra note 26 at 21.

${ }^{46}$ See, in detail, Balagangadhara, The Heathen, supra note 17, especially at 65-140.

${ }^{47}$ See also, G. A. Oddie, Imagined Hinduism: British Protestant Missionary Constructions of Hinduism, 1793-1900 (New Delhi: SAGE Publications, 2006); R. Gelders \& S. N. Balagangadhara, "Rethinking Orientalism: Colonialism and the Study of Indian Traditions" (2011) 51 History of Religions 101.

${ }^{48}$ Harjot Oberoi, The Construction of Religious Boundaries: Culture, Identity and Diversity in the Sikh Tradition (Delhi: Oxford University Press, 1995). See also Roger Ballard, "Panth, Kismet, Dharm te Quam: Continuity and
} 
work of converting Indian traditions into a series of 'religions' was underway, once more instantiating the process of anothering.

As De Roover and Balagangadhara have explained, British legal recognition followed the understanding that the rulers should not intervene in the affairs of the conscience of their Indian subjects. ${ }^{49}$ The British were reading Indian society according to their own understanding of statereligion relations and, specifically, their respect for indigenous legal traditions followed the requirements of liberal toleration originating in the Protestant Reformation. The legal rules of the populace were to be found in textual sources and defence of indigenous mores, for example the practice of sati, also came to be based on the textual origin of the practices. This way of acting evidently mirrored the Christian understanding, privileging the sacred text as the source of the beliefs motivating practices. ${ }^{50}$ It was thus that the 'secular' state in India emerged in the early modern period setting the basic contours of the debate on non-interference in the personal laws of Indians that continued well into the post-colonial period. The recourse to textual sources for the ascertainment of indigenous laws was supplemented by consulting experts in the shastra, a practice that came to be abandoned, and replaced by forcing Hindu law into the framework of the common law. Portions of it were reformed by statute on the ground that certain practices, such as child marriage, needed to be rooted out, and this was often championed by Indians working in the colonial legal system.

\footnotetext{
Change in Four Dimensions of Punjabi Religion" in Pritam Singh \& Shinder S. Thandi, eds, Globalisation and the Region: Explorations in Punjabi Identity (Coventry: Association for Punjab Studies, 1996) 7.

${ }^{49}$ Jakob De Roover \& S.N. Balagangadhara, "Liberty, Tyranny and the Will of God: The Principle of Toleration in Early Modern Europe and Colonial India” (2009) 30 History of Political Thought 111.

${ }^{50}$ The textual emphasis is observed repeatedly as integral to the rise of Orientalism by Edward Said, Orientalism (New York: Pantheon Books, 1978).
} 
However, as De Roover observes, the idea of purifying Hindu law of its man-made accretions never went away. ${ }^{51}$ De Roover shows that although the language of 'false religion' and 'idolatry' was no longer significantly invoked by agents of the secular state from the $19^{\text {th }}$ century, the idea remained implicit in the reforms by the secular colonial Indian state in that it was held that the 'pure' elements of Hindu law should be distilled and observed, in so doing undermining the diversity of Indian traditions. Repeated attempts were made to write codes reflecting a distillation of Hindu law in this way, while subjection to the English paradigm of judge-made law did its own work in undermining customs. ${ }^{52}$ As De Roover notes, "The conceptual realm of false religion had been secularized in the sense that it became an implicit criterion presented as though it were internal to Hindu religion" (italics in original). ${ }^{53}$

It appears as though the idea of doing away with Indian traditions was revivified in the early post-colonial era when a major attempt at reforms to the Hindu personal law was made. Rhetorically, at least, the principle that there would be no interference in the personal law of a community without a demand from that community was observed. That was until the 1930s when changes were made to Muslim law on the basis of demands by ulema, who portrayed themselves as representing the Muslim community, after a sustained campaign for asserting the primacy of Islamic law over custom among Muslims. ${ }^{54}$ Rina Verma Williams, who develops a fascinating account of the continuity between the colonial and post-colonial periods in Indian state policy regarding personal law, says that:

\footnotetext{
${ }^{51}$ Jakob De Roover, "Secular Law" supra note 33 at 51-6.

${ }^{52}$ Werner F. Menski, Hindu Law: Beyond Tradition and Modernity (Delhi: Oxford University Press, 2003) at 156208.

${ }^{53}$ Jakob De Roover, "Secular Law" supra note 33 at 55.

${ }^{54}$ Rina Verma Williams, Postcolonial Politics and Personal Laws: Colonial Legal Legacies and the Indian State (New Delhi: Oxford University Press, 2006) at 83-8.
} 
The government would claim to be following community opinion but in reality few systematic attempts were made to determine what that opinion might actually be. Where there was evidence of community opinion, it was often divided and inconclusive. Ultimately, government leaders relied on the views of a faction of community leaders (religious and/or political) that supported the position the government advocated. ${ }^{55}$

Statutory reforms of Hindu law were championed already prior to the independence but were pushed to the fore in its aftermath by the reformist Prime Minister, Jawaharlal Nehru, and B. R. Ambedkar, the first Law Minister, who had already successfully included Article 44 as a Directive Principle looking to a future Uniform Civil Code. Nehru assured Muslim spokespersons that, "personal law is part of religion. It is obvious that no change can be imposed from the top" ${ }^{56}$ The reform to Hindu law resulted in four pieces of legislation referred to as the "Hindu Code Bill" (the language is itself reminiscent of the earlier colonial debates on codification) reforming various aspects of Hindu law. The legislation was applied to those who are Hindus "by religion", but included Buddhists, Jains and Sikhs. It was resisted by the Hindu Mahasabha and some prominent members of the ruling Congress party, including the President, Rajendra Prasad, and Vallabhai Patel, and concessions were demanded, especially as to the recognition of custom, while the Hindu joint family system fell out of the scope of the legislation. $^{57}$

The Hindu legislation of the 1950s can be interpreted in a number of ways: one may conclude that it was a messy compromise not achieving much in the end; that it left out of its scope much of relevance; and it was not in fact the first step toward the achievement of the Uniform Civil

\footnotetext{
${ }^{55}$ Ibid at 10 .

${ }^{56}$ Quoted in ibid at 102.

${ }^{57}$ Ibid at $109-13$.
} 
Code because, significantly, Muslim personal law has remained largely out of reach of legislative change. ${ }^{58}$ There is, however, another way to look at the matter. The proponents of the 1950s reform often justified it by saying that they merely continued what the British had initiated and questioned why there should be an objection now that an 'indigenous' government was doing the same work. Advocates for reform, notably Nehru, were also deeply impressed by the idea of a secular state, seeing religion as superstitious dogma responsible for conflict. The ideal was that a Uniform Civil Code of India should show no trace of religion, and the first candidates for reform should be the Hindus. Menski, noting the lack of any desire for general reform of the legal system inherited from the colonial state, sums up the background thinking and the results:

The approach to Hindu personal law appeared to be quite different, however, as the modernizing post-colonial state developed an appetite and ambition for personal law reform. The ambition had been nurtured during the final decades of British rule, partly as a result of the British forms of 'civilizing mission' and its perceived fruits in the form of social reform movements. Almost by definition, the modernization of Hindu law in India was perceived as a historical opportunity for removing 'tradition', a chance to wipe out the remaining vestiges of traditional norms in the Hindu personal law as they had developed and sheltered under Anglo-Hindu law. It was a revolution, but it remained by its nature incomplete. In reality, despite all the hype, the reformed law was no more than a half-way house in the ongoing legal process of harmonizing law and society. ${ }^{59}$

As Menski observes here, the 1950s reforms to Hindu law were a continuation of the civilizing mission started by the British and founded on hostility to tradition. According to the reading of

\footnotetext{
${ }^{58}$ Ibid at $113-120$.

${ }^{59}$ Menski, Hindu Law supra note 52 at 211.
} 
developments proffered here, it appears as though the task, initiated by the colonial masters with their Protestant background, of removing idolatrous practices of a false religion, had been taken over by the post-colonial state. However incomplete this process may have been, as Menski notes throughout his major work, ${ }^{60}$ the continuous problematization has made a conceptualization of Hindu law, or Indian traditional laws in general, as centrally composed of diverse ancestral practices, ever more difficult to articulate. Consequently, they are constantly pushed into the 'unofficial' sphere, as Chiba might say, where they continue to exercise their pull.

\section{Concluding thoughts}

We can return to think again about Chiba's observation that the preservation of a people's cultural identity in law, in the face of transplanted law from foreign countries, is conditioned by their identity postulate of indigenous law. In light of this hypothesis how should we evaluate what has occurred to Japanese and Indian people when they have absorbed a predominantly Protestant Christian framework of law? In the case of the absorption of the Western norm of religion and the secular, and its linked concepts such as religious freedom, the separation of religion and state, etc. the evidence indicates that the state systems in Japan and India have come to assume an alien, religious identity, have transformed their understanding of their own people, and they have attempted to reform the law of their people in accordance with this alien framework of secularization. In the process, the people have become just another group of religious people and they now experience 'religious' nationalism, religious conflict, and battles for their religious rights. Their experience has come to be distorted and occluded in part through ${ }^{60}$ Ibid. 
the agency of their official legal systems. Balagangadhara speaks of 'colonial consciousness' to refer to the absorption of experience occluding structures of religion with respect to Indian culture. ${ }^{61}$ Should we apply the same reading to the Japanese case even though there is no direct colonial relationship between Japan and the West? What is the role of violence here? Where does it leave Chiba's hypothesis that the identity postulate of indigenous law is the mechanism of retention of a people's cultural identity? What implications do the findings presented here have for steering a future course of action for the study of Asian legal systems?

\footnotetext{
${ }^{61}$ S.N. Balagangadhara, "Secularism as the Harbinger of Religious Violence in India: Hybridisation, Hindutva and Post-Coloniality' in D. Schirmer, G. Saalmann, \& C. Kessler, eds, Hybridising East and West: Tales beyond Westernisation (Berlin, LIT Verlag, 2006) 145; S.N. Balagangadhara, Reconceptualizing India Studies (New Delhi: Oxford University Press, 2012).
} 